Journal of Community Based Environmental Engineering and Management, 2019, Vol. 3, No. 2: 65-78

\title{
THE USE OF MULTI-CRITERIA ANALYSIS IN SELECTING WATER TREATMENT UNITS IN SADU WATER TREATMENT PLANT, BANDUNG DISTRICT, WEST JAVA PROVINCE, INDONESIA
}

\author{
Riana Ayu Kusumadewi*, Indry Kemala Sani, and Winarni \\ Department of Environmental Engineering, Universitas Trisakti
}

\begin{abstract}
Increasing the number of residents and still not fulfilling the scope of drinking water services for resident of Bandung Regency, Tirta Raharja Regional Water Supply Company is developing in the field of drinking water supply. To improve community drinking water services in the Bandung Regency area, Tirta Raharja Water Supply Company plans to add a drinking water treatment plant with a capacity of 150 liters/second located in Sadu Village, Soreang District, Bandung Regency. This research aims to use of multi-criteria analysis in selecting water treatment units in Sadu WTP. In the planning of the Sadu WTP (Sadu Water Treatment Plant) was carried out several stages of planning, i.e. literature study, preliminary survey, data collection, alternative selection of treatment units using multi criteria analysis, and calculation of treatment unit dimensions. The parameters under review are those that exceed the standard of quality according to the Minister of Health Regulation No. 492 of 2010, i.e. turbidity, BOD, COD and fecal coliform. The selection of Sadu WTP units is based on parameters that exceed drinking water quality standards. There were two alternative proposed (Alternative I and Alternative II) in drinking water treatment, i.e. complete unit (Alternative I) consisting of intake; hydraulic coagulation; hydraulic flocculation; tube settler sedimentation; rapid sand filter; reservoir; disinfection; and sludge drying bed, and slow sand filter unit (Alternative II) consisting of intake, pre-sedimentation, slow sand filter, reservoir, disinfection, and sludge drying bed. The method to be used in determining the unit plan is multi-criteria analysis which refers to aspects based on Minister of Public Works Regulation No. 18/PRT/M/2007. Based on the results of the scoring obtained, the complete treatment unit has the highest score, i.e. 4.05, so the alternative treatment used in the Sadu WTP is the complete treatment unit (Alternative I).
\end{abstract}

Keywords: alternative water treatment, multi criteria analysis, water treatment plant, water quality

\section{Introduction}

Drinking water is one of the sanitation needs of humankind (Hasbiah et.al, 2019). The demand for water worldwide has increased substantially over the past decades. Development analysts

\footnotetext{
${ }^{*}$ Penulis Korespondensi:

E-mail: rianaayu.kusumadewi@trisakti.ac.id

Diterima pertama kali: 1 September 2019

Direvisi : 11 September 2019

Disetujui untuk publikasi: 12 September 2019
}

attribute it to the growing population numbers, increased irrigation areas, economic development and acute water shortage in many parts of the world. This development has resulted in the drying up of rivers. The issues concerning water usage are sectoral and affect both inputs and outputs of the national and international economics. The agricultural sector, production of energy, industrial uses, and human consumption are the main areas where the demand for water is high. Among the sectors 
enumerated, livestock and the crops production sector are the intensive-users of water (Udimal et.al, 2017).

Water treatment plants (WTPs) are characterized as complex configurations of repairable and deteriorating components (Smith et.al, 2019). Water suppliers are a variety of treatment processes to remove contaminants from raw water. These individual processes may be arranged in a "treatment train" (a series of processes applied in sequence). The most commonly used processes include filtration, flocculation and sedimentation and disinfection for surface water. Some treatment trains also include ion exchange and adsorption. Water utilities select a combination of treatment processes that is the most appropriate to treat the contaminants found in the raw water (Angreni, 2009).

The restriction of water's resources, the need of a careful management and the importance to ensure a good water quality are now more obvious than ever. Treatment of water is accomplished through process of mechanical nature (retention on grates and separators, sediment exclusion, decantation, filtration), of chemical nature (coagulation-flocculation, ion exchange, chlorination, disinfection with UV radiations, aeration-oxidation) and of biological nature (adsorption on active coal, biological treatment using slow filter or semi - permeable membrane) (Oana et.al, 2011).

Increasing the number of residents and still not fulfilling the scope of drinking water services for resident of Bandung Regency, Tirta Raharja Regional Water Supply Company is developing in the field of drinking water supply. Tirta Raharja Water Supply Company currently serves three administrative regions, i.e. Bandung Regency, Cimahi City and West Bandung Regency. In Bandung Regency, there are six branches or service units. The total production capacity of Tirta Raharja Water Supply
Company in Bandung Regency until 2018 is 885 liters/second with six Water Treatment Plants (WTPs) divided into three service areas, i.e. the south, north and east. Tirta Raharja Water Supply Company until 2018 has had 97,329 subscription connections. To improve community drinking water services in the Bandung Regency area, Tirta Raharja Water Supply Company plans to add a drinking water tratment plant with a capacity of 150 liters/second located in Sadu Village, Soreang District, Bandung Regency.

\section{Analysis Method}

In the planning of the Sadu WTP (Sadu Water Treatmnet Plant) was carried out several stages of planning, i.e. literature study, preliminary survey, data collection, alternative selection of treatment units using multi criteria analysis, and calculation of treatment unit dimensions.

\section{Preliminary Survey}

The preliminary survey was intended to provide a direct observation of the actual location of the planning area.

\section{Data Collection}

Sampling of raw water was taken from the location of the intake plan using the Grab Sampling method. Samples were taken three times during rainy or wet seasons and three times in dry seasons. The raw water sampling was carried out in accordance with SNI 7828: 2012 with the sampling done at a depth of approximately half the river depth.

\section{Multi Criteria Analysis}

An alternative analysis of the treatment unit was conducted to select an effective and efficient treatment unit based on the Cisondari River water quality that exceeds the standard according to Minister of Health Regulation No. 492 of 2010. The method to be used in determining the unit plan is multi-criteria analysis which refers to aspects based on 
Minister of Public Works Regulation No. 18/PRT/M/2007.

\section{Calculation of Treatment Units}

Calculation of selected unit dimensions was conducted using the design criteria obtained from the existing WTP evaluation, namely the Cipageran WTP. Evaluations for Sadu WTP can be calculated by the equation below (Qasim, 2000):

$\begin{array}{ll}\text { Velocity } & \mathrm{v}=\frac{Q}{A} \\ \text { Detention time } & \mathrm{t}_{\mathrm{d}}=\frac{V}{Q} \\ \text { Gradien } & \mathrm{G}=\sqrt{\frac{P}{\mu x V}} \\ \text { Hydraulic Gradien } & \mathrm{Gt}_{\mathrm{d}}=\mathrm{G} \times \mathrm{t}_{\mathrm{d}} \\ \text { Reynolds number } & \mathrm{N}_{\mathrm{Re}}=\frac{V p x R}{v} \\ \text { Froude number } & \mathrm{N}_{\mathrm{Fr}}=\frac{V p^{2}}{g x R}\end{array}$

Where $\mathrm{Q}$ is discharge of raw water $\left(\mathrm{m}^{3} /\right.$ second), $\mathrm{V}$ is tank volume $\left(\mathrm{m}^{3}\right), \mu$ is absolute viscocity ( $\mathrm{kg} / \mathrm{m}$. second), and $\rho$ is density $\left(\mathrm{kg} / \mathrm{m}^{3}\right)$.

\section{Result and Discussion}

Raw Water Quality Analysis

In Sadu WTP plan, the source of raw water used is sourced from the upper reaches of the
Cisondari River with a planned capacity of 150 liters/second. The selection of the Cisondari River as a source of raw water is due to the Cisondari River's minimum discharge still meets the capacity of the plan if tapping is carried out and the quality of the Cisondari River still meets the requirements as a source of drinking water.

Sampling of raw water was done in two seasons, i.e. dry and wet seasons. Sampling of raw water that represents the wet season was conducted on January 28, 2019, while sampling of raw water representing the dry season was conducted on March 12, 2019. The results of the analysis of the raw water quality of the Cisondari River were then compared with Government Regulation No. 82 of 2011 Class I concerning Water Quality Management to see the feasibility of Cisondari River water as raw water that will be processed into drinking water. The results of the analysis were also compared with Minister of Health Regulation No. 492 of 2010 concerning Drinking Water Quality Requirements to determine parameters that exceed drinking water standards. The results of the analysis of raw water quality is shown in Table 1.

Table 1. Comparison of Raw Water Quality Results with Government Regulation No. 82 of 2001 and Minister of Health Regulation No. 492 of 2010

\begin{tabular}{|c|c|c|c|c|c|c|}
\hline \multirow[b]{2}{*}{ No. } & \multirow[b]{2}{*}{ Parameters } & \multirow[b]{2}{*}{ Units } & \multirow{2}{*}{$\begin{array}{l}\text { Government } \\
\text { Regulation No. } \\
82 \text { of } 2011\end{array}$} & \multirow{2}{*}{$\begin{array}{c}\text { Minister of } \\
\text { Health } \\
\text { Regulation No. } \\
492 \text { of } 2010 \\
\end{array}$} & \multicolumn{2}{|c|}{ Results } \\
\hline & & & & & $\begin{array}{c}\text { March 12, } \\
2019\end{array}$ & $\begin{array}{c}\text { January 28, } \\
2019\end{array}$ \\
\hline \multicolumn{7}{|c|}{ A. Physics } \\
\hline 1 & Temperature & ${ }^{\circ} \mathrm{C}$ & Deviation 3 & $\begin{array}{c}\text { Air temperature } \\
\pm 3^{\circ} \mathrm{C}\end{array}$ & 24 & 26 \\
\hline 2 & Turbidity & $\mathrm{mg} / \mathrm{l}$ & - & 5 & 7.5 & 28.3 \\
\hline 3 & $\begin{array}{l}\text { Total Dissolved Solid } \\
\text { (TDS) }\end{array}$ & $\mathrm{mg} / \mathrm{l}$ & 1000 & 500 & 14 & 17 \\
\hline 4 & $\begin{array}{l}\text { Total Suspended Solid } \\
\text { (TSS) }\end{array}$ & $\mathrm{mg} / \mathrm{l}$ & 50 & - & 54 & 7.7 \\
\hline \multicolumn{7}{|c|}{ Chemistry } \\
\hline 1 & $\mathrm{pH}$ & - & - & $6.5-8.5$ & 7.2 & 7.2 \\
\hline 2 & $\mathrm{BOD}_{5}$ & $\mathrm{mg} / \mathrm{l}$ & 2 & 2 & 0.7 & 11 \\
\hline 3 & COD & $\mathrm{mg} / \mathrm{l}$ & 10 & 10 & 1.59 & 35.4 \\
\hline 4 & Dissolved Oxygen (DO) & $\mathrm{mg} / \mathrm{l}$ & 6 & - & 4.63 & 7.4 \\
\hline
\end{tabular}




\begin{tabular}{|c|c|c|c|c|c|c|}
\hline \multirow[b]{2}{*}{ No. } & \multirow[b]{2}{*}{ Parameters } & \multirow[b]{2}{*}{ Units } & \multirow{2}{*}{$\begin{array}{l}\text { Government } \\
\text { Regulation No. } \\
82 \text { of } 2011\end{array}$} & \multirow{2}{*}{$\begin{array}{c}\text { Minister of } \\
\text { Health } \\
\text { Regulation No. } \\
492 \text { of } 2010\end{array}$} & \multicolumn{2}{|c|}{ Results } \\
\hline & & & & & $\begin{array}{l}\text { March 12, } \\
2019\end{array}$ & $\begin{array}{c}\text { January 28, } \\
2019\end{array}$ \\
\hline 5 & Total phosphate $\left(\mathrm{PO}_{4}-\mathrm{P}\right)$ & $\mathrm{mg} / \mathrm{l}$ & 0.2 & - & 0.65 & 0.02 \\
\hline 6 & Nitrate $\left(\mathrm{NO}_{3}-\mathrm{N}\right)$ & $\mathrm{mg} / \mathrm{l}$ & 10 & 50 & 0.67 & 0.8 \\
\hline 7 & Nitrite $\left(\mathrm{NO}_{2}\right)$ & $\mathrm{mg} / \mathrm{l}$ & - & 3 & $<0.01$ & $<0.026$ \\
\hline 8 & Free ammonia $\left(\mathrm{NH}_{3}-\mathrm{N}\right)$ & $\mathrm{mg} / \mathrm{l}$ & 0.5 & 1.5 & $<0.05$ & $<0.0618$ \\
\hline 9 & $\operatorname{Arsen}(\mathrm{As})$ & $\mathrm{mg} / \mathrm{l}$ & 0.05 & - & $<0.002$ & $<0.002$ \\
\hline 10 & Cobalt (Co) & $\mathrm{mg} / \mathrm{l}$ & 0.2 & - & $<0.04$ & $<0.076$ \\
\hline 11 & Barium $(\mathrm{Ba})$ & $\mathrm{mg} / \mathrm{l}$ & 1 & - & $<0.12$ & $<0.0419$ \\
\hline 12 & Selenium $(\mathrm{Se})$ & $\mathrm{mg} / \mathrm{l}$ & 0.01 & 0.01 & $<0.001$ & $<0.001$ \\
\hline 13 & Cadmium $(\mathrm{Cd})$ & $\mathrm{mg} / \mathrm{l}$ & 0.01 & - & $<0.003$ & $<0.0016$ \\
\hline 14 & $\begin{array}{l}\text { Chromium hexavalent } \\
(\mathrm{Cr}(\mathrm{VI}))\end{array}$ & $\mathrm{mg} / \mathrm{l}$ & 0.05 & - & $<0.02$ & $<0.005$ \\
\hline 15 & Copper $(\mathrm{Cu})$ & $\mathrm{mg} / \mathrm{l}$ & 0.02 & 2 & $<0.02$ & $<0.0083$ \\
\hline 16 & Iron $(\mathrm{Fe})$ & $\mathrm{mg} / \mathrm{l}$ & 0.3 & 0.3 & $<0.04$ & $<0.01$ \\
\hline 17 & Lead $(\mathrm{Pb})$ & $\mathrm{mg} / \mathrm{l}$ & 0.03 & - & $<0.02$ & $<0.022$ \\
\hline 18 & Manganese (Mn) & $\mathrm{mg} / \mathrm{l}$ & 0.1 & 0.4 & $<0.02$ & $<0.1$ \\
\hline 19 & Mercury (Hg) & $\mathrm{mg} / \mathrm{l}$ & 0.001 & - & $<0.0008$ & $<0.0005$ \\
\hline 20 & Zinc $(\mathrm{Zn})$ & $\mathrm{mg} / \mathrm{l}$ & 0.05 & 3 & $<0.01$ & $<0.005$ \\
\hline 21 & Chloride $(\mathrm{Cl})$ & $\mathrm{mg} / \mathrm{l}$ & 600 & 250 & $<1.9$ & 35.4 \\
\hline & Cyanide $(\mathrm{CN})$ & $\mathrm{mg} / \mathrm{l}$ & 0.02 & 0.07 & $<0.01$ & $<0.005$ \\
\hline & Fluoride $(\mathrm{F})$ & $\mathrm{mg} / \mathrm{l}$ & 0.5 & - & $<0.05$ & $<0.92$ \\
\hline \multicolumn{7}{|c|}{ C. Microbiology } \\
\hline 1 & Fecal coliform & $\begin{array}{c}\text { cell/100 } \\
\mathrm{ml}\end{array}$ & 100 & - & 0 & $<3$ \\
\hline 2 & E. Coli & $\begin{array}{c}\text { cell } / 100 \\
\mathrm{ml}\end{array}$ & - & 0 & 0 & 3 \\
\hline 3 & Total coliform & $\begin{array}{c}\text { cell/100 } \\
\mathrm{ml}\end{array}$ & 1000 & 0 & 36 & 3 \\
\hline
\end{tabular}

Remarks:

$\square=$ Parameter that exceed quality standards_

As illustrated in Table 1, it is shown that there were parameters that exceed the standards, i.e. turbidity, total suspended solid (TSS), biological oxygen demand (BOD), chemical oxygen demand (COD), dissolved oxygen (DO), total phosphate $\left(\mathrm{PO}_{4}-\mathrm{P}\right)$, E.coli, and total coliform. Therefore, water treatment is needed so that raw water sources can be used as drinking water. However in designing drinking water treatment, the parameters under review are those that exceed the standard of quality according to the Minister of Health Regulation No. 492 of 2010, i.e. turbidity, BOD, COD and fecal coliform.

\section{Drinking Water Treatment Alternatives}

The selection of Sadu WTP units is based on parameters that exceed drinking water quality standards. Coagulation, flocculation, and sedimentation units are used to remove turbidity, TSS, BOD, COD, total phosphate, fecal coliform and total coliform parameters. The filtration unit can remove turbidity, fecal coliform, E.coli, and total coliform parameters. Alternative water treatment plants in Sadu WTP can be seen in Table 2 . 
Table 2. Alternative Water Treatment Plants in Sadu WTP

\begin{tabular}{|c|c|c|c|c|c|c|c|c|c|c|c|c|c|c|c|c|c|c|}
\hline \multirow[b]{2}{*}{ No } & \multicolumn{4}{|c|}{ Drinking Water Quality } & \multirow[b]{2}{*}{ Units } & \multicolumn{6}{|c|}{ Pretreatments } & \multicolumn{2}{|c|}{ Treatments } & \multicolumn{5}{|c|}{ Special Treatments } \\
\hline & Parameters & $\begin{array}{c}\text { Dry Season } \\
\text { Measurement }\end{array}$ & $\begin{array}{c}\text { Wet Season } \\
\text { Measurement }\end{array}$ & $\begin{array}{c}\text { Quality } \\
\text { Standard } \\
*)\end{array}$ & & S & PC & PS & A & LS & $\mathrm{CS}$ & RSF & SSF & $P$ & $\mathrm{SC}$ & $\mathrm{AC}$ & SCT & SWT \\
\hline 1 & Turbidity & 7.5 & 28.3 & 5 & NTU & & & $\sqrt{ }$ & & & $\sqrt{ }$ & $\sqrt{ }$ & $\sqrt{ }$ & & & & & \\
\hline 2 & BOD & 0.7 & 11 & 2 & $\mathrm{mg} / \mathrm{l}$ & & & & & & $\sqrt{ }$ & & $\sqrt{ }$ & & & & & \\
\hline 3 & COD & 1.59 & 35.4 & 10 & $\mathrm{mg} / \mathrm{l}$ & & & & & & $\sqrt{ }$ & & $\sqrt{ }$ & & & & & \\
\hline 4 & $\begin{array}{l}\text { Fecal } \\
\text { coliform }\end{array}$ & 0 & 3 & 0 & $\begin{array}{c}\text { MPN/ } \\
100 \\
\mathrm{ml}\end{array}$ & & & & & & $\sqrt{ }$ & $\sqrt{ }$ & $\sqrt{ }$ & $\sqrt{ }$ & & & & \\
\hline \multirow[t]{2}{*}{5} & $\begin{array}{l}\text { Total } \\
\text { coliform }\end{array}$ & 36 & 3 & 0 & $\begin{array}{c}\text { MPN/ } \\
100 \\
\mathrm{ml}\end{array}$ & & & & & & $\sqrt{ }$ & $\sqrt{ }$ & $\sqrt{ }$ & $\sqrt{ }$ & & & & \\
\hline & $\begin{array}{ll}\text { Remarks: } \\
\sqrt{ } & =\mathrm{U} \\
*) & =\mathrm{M} \\
\mathrm{S} & =\mathrm{Sc} \\
\mathrm{PC} & =\mathrm{Pr} \\
\mathrm{PS} & =\mathrm{Pr} \\
\mathrm{A} & =\mathrm{A} \\
\mathrm{LS} & =\mathrm{Li} \\
\mathrm{CS} & =\mathrm{C}\end{array}$ & $\begin{array}{l}\text { t used } \\
\text { hister of Heal } \\
\text { eening } \\
\text { Chlorination } \\
\text {-sedimentatio } \\
\text { ation } \\
\text { he Softening } \\
\text { gulation - fl }\end{array}$ & h Regulation & No. 492 o & 2010 & & $\begin{array}{l}\text { R } \\
\text { SS } \\
\text { P } \\
\text { SC } \\
\text { A } \\
\text { SC } \\
\text { St }\end{array}$ & $\mathrm{T}$ & $\begin{array}{l}=1 \\
= \\
=1 \\
= \\
= \\
= \\
=\end{array}$ & $\begin{array}{l}\text { Rapi } \\
\text { Slow } \\
\text { Post } \\
\text { Supe } \\
\text { Acti } \\
\text { Spec } \\
\text { Salt }\end{array}$ & $\begin{array}{l}\text { San } \\
\text { Sanc } \\
\text { Chlo } \\
\text { Chl } \\
\text { ated } \\
\text { al C } \\
\text { Vate }\end{array}$ & $\begin{array}{l}\text { I Filt } \\
\text { Filte } \\
\text { natio } \\
\text { rinat } \\
\text { Carbo } \\
\text { emicc } \\
\text { Trea }\end{array}$ & $\begin{array}{l}\text { n } \\
\text { Tre } \\
\text { nent }\end{array}$ & me & & & & \\
\hline
\end{tabular}

\section{A. Drinking Water Treatment Alternative I} Based on the raw water parameter data that needs to be removed, Alternative I combination of operating and processing units that more specific are as follows:

1. Intake;

2. Hydraulic coagulation;

3. Hydraulic flocculation;

4. Tube settler $60^{\circ}$ sedimentation;

5. Rapid sand filter;

6. Reservoir;

7. Disinfection using chlorine chemicals in the reservoir;

8. Sludge treatment using sludge drying bed.

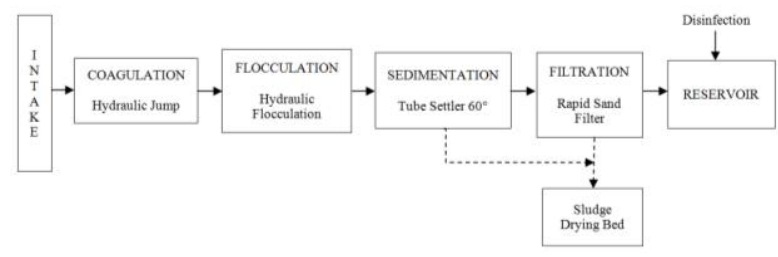

Figure 2. Scheme of Drinking Water Treatment Alternative I.

\section{B. Drinking Water Treatment Alternative II}

Based on the raw water parameter data that needs to be removed, Alternative II combination of operating and processing units that more specific are as follows:

1. Intake;

2. Pre-sedimentation;

3. Slow sand filter;

4. Reservoir;

5. Disinfection using chlorine chemicals in the reservoir;

6. Sludge treatment using sludge drying bed.

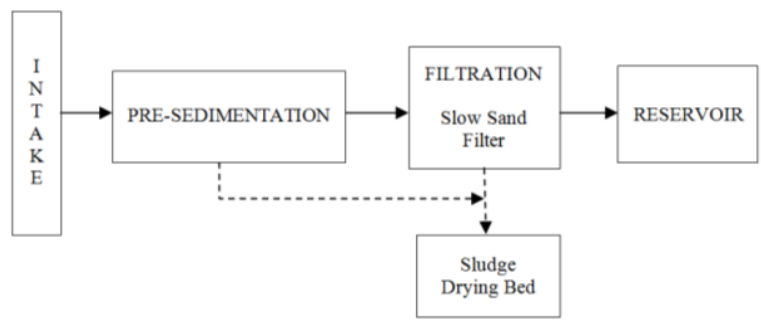

Figure 3. Scheme of Drinking Water Treatment Alternative II.

Multi-criteria Analysis in Selecting Water Treatment Units

There were two alternative proposed (Alternative I and Alternative II) in drinking water treatment, i.e. complete unit (Alternative I) consisting of intake; hydraulic coagulation; hydraulic flocculation; tube settler sedimentation; rapid sand filter; reservoir; 
disinfection; and sludge drying bed, and slow sand filter unit (Alternative II) consisting of intake, pre-sedimentation, slow sand filter, reservoir, disinfection, and sludge drying bed. Based on alternative unit choices available, an appropriate method is needed to determine the treatment units that will be used in the WTP plan. The method to be used in determining the

Table 3. Classification of Weighting Multi-Criteria Aspects

\begin{tabular}{|c|c|c|c|}
\hline No. & Criteria & Weight Percentage & Description/Reasons for Weighting \\
\hline \multicolumn{4}{|c|}{ Technical Aspects } \\
\hline 1 & $\begin{array}{l}\text { Removal efficiency } \\
\text { in treatment process }\end{array}$ & $20 \%$ & $\begin{array}{l}\text { This aspect is influential due to the higher the treatment } \\
\text { efficiency, the better the quality produced. }\end{array}$ \\
\hline 2 & $\begin{array}{l}\text { The flexibility of the } \\
\text { treatment system to } \\
\text { quality fluctuations }\end{array}$ & $10 \%$ & $\begin{array}{l}\text { This aspect is not very influential due to the treated water } \\
\text { discharge has been adjusted to the provisions of the } \\
\text { planned discharge, and the quality of the Cisondari River } \\
\text { is not fluctuate too much due to it is located upstream of } \\
\text { the river. }\end{array}$ \\
\hline 3 & Construction & $5 \%$ & $\begin{array}{l}\text { This aspect is not very influential due to construction } \\
\text { seen from the level of simplicity. The easier the } \\
\text { construction of a treatment plant, the better it will be. }\end{array}$ \\
\hline 4 & $\begin{array}{l}\text { Operational and } \\
\text { maintenance }\end{array}$ & $15 \%$ & $\begin{array}{l}\text { This aspect has an effect on the operation in accordance } \\
\text { with the SOP for the workings of the WTP. }\end{array}$ \\
\hline 5 & $\begin{array}{l}\text { Availability of WTP } \\
\text { material units }\end{array}$ & $5 \%$ & $\begin{array}{l}\text { This aspect is quite influential due to the material needed } \\
\text { affects the construction to be constructed. }\end{array}$ \\
\hline 6 & Possible damage & $5 \%$ & $\begin{array}{l}\text { This aspect is not very influential because if a unit plan is } \\
\text { very concerned about operational and maintenance } \\
\text { factors of the unit, the possibility of damage is small. }\end{array}$ \\
\hline \multicolumn{4}{|c|}{ Economic Aspects } \\
\hline 7 & $\begin{array}{l}\text { The land area } \\
\text { required }\end{array}$ & $10 \%$ & $\begin{array}{l}\text { This aspect is quite influential due to alternative WTP } \\
\text { units will be made by requiring a large enough land for } \\
\text { planning. }\end{array}$ \\
\hline 8 & $\begin{array}{l}\text { Unit operating and } \\
\text { maintenance costs }\end{array}$ & $15 \%$ & $\begin{array}{l}\text { This aspect needs to be considered, due to these costs will } \\
\text { be incurred while the unit is operating. These costs } \\
\text { include energy costs incurred, costs for chemicals used, } \\
\text { the cost of residue treatment, and salaries of } \\
\text { employees/labors. }\end{array}$ \\
\hline 9 & Construction costs & $10 \%$ & $\begin{array}{l}\text { This aspect is considered due to construction costs are } \\
\text { costs incurred at the beginning of construction. }\end{array}$ \\
\hline \multicolumn{4}{|c|}{ Environmental Aspects } \\
\hline 10 & $\begin{array}{l}\text { Ecological balance, } \\
\text { environmental } \\
\text { carrying capacity } \\
\text { and land use }\end{array}$ & $5 \%$ & $\begin{array}{l}\text { This aspect is not too much of a consideration in choosing } \\
\text { a drinking water treatment, due to every residue produced } \\
\text { will be reprocessed so that it does not pollute the } \\
\text { environment. }\end{array}$ \\
\hline
\end{tabular}

Weights in this aspect will be used as an assessment of the available alternative units by comparing the strengths and weaknesses of each alternative choice. The assessment is conducted by giving a score of 1 to 5 , the higher the score obtained for each unit, the better the unit plan is multi-criteria analysis which refers to aspects based on Minister of Public Works Regulation No. 18/PRT/M/2007. Each aspect is given a different weight. The total weight for all aspects is $100 \%$. The weighting classification is shown in Table 3. 
Table 4. Comparison of Alternative I and Alternative II Scores

\begin{tabular}{|c|c|c|c|c|c|}
\hline \multirow[t]{2}{*}{ Criteria } & \multirow[t]{2}{*}{ Weight (\%) } & \multicolumn{2}{|c|}{$\begin{array}{l}\text { Complete Treatment Unit } \\
\text { (Alternative I) }\end{array}$} & \multicolumn{2}{|c|}{$\begin{array}{c}\text { Slow Sand Filter } \\
\text { (Alternative II) }\end{array}$} \\
\hline & & Value & Score & Value & Score \\
\hline \multicolumn{6}{|c|}{ Technical Aspects } \\
\hline 1 & $20 \%$ & 5 & 1 & 3 & 0.6 \\
\hline 2 & $10 \%$ & 5 & 0.5 & 3 & 0.3 \\
\hline 3 & $5 \%$ & 4 & 0.2 & 5 & 0.25 \\
\hline 4 & $15 \%$ & 3 & 0.45 & 4 & 0.6 \\
\hline 5 & $5 \%$ & 3 & 0.15 & 4 & 0.2 \\
\hline 6 & $5 \%$ & 5 & 0.25 & 4 & 0.2 \\
\hline \multicolumn{6}{|c|}{ Economic Aspects } \\
\hline 7 & $10 \%$ & 4 & 0.4 & 5 & 0.5 \\
\hline 8 & $15 \%$ & 4 & 0.6 & 5 & 0.75 \\
\hline 9 & $10 \%$ & 3 & 0.3 & 4 & 0.4 \\
\hline \multicolumn{6}{|c|}{ Environmental Aspects } \\
\hline 10 & $5 \%$ & 4 & 0.2 & 3 & 0.15 \\
\hline Total & $100 \%$ & & 4.05 & & 3.95 \\
\hline
\end{tabular}

Based on the results of the scoring obtained, the complete treatment unit has the highest score, so the alternative treatment used in the Sadu WTP is the complete treatment unit (Alternative I). After determining the alternative treatment selected, then it can be determined the type of drinking water treatment to be used. Drinking water treatment unit recommendation can be seen in Table 5.

Table 5. Sadu WTP Alternative Treatment Unit Selected

\begin{tabular}{|c|c|c|}
\hline No. & Selected Unit & Recommendation \\
\hline 1 & Intake & $\begin{array}{l}\text { The intake that will used in the planning of Sadu WTP is river intake. Water from } \\
\text { the Cisondari River is flowed to the collection basin using a carrier channel. Raw } \\
\text { water flows to the location of the treatment unit by gravity. }\end{array}$ \\
\hline 2 & Coagulation & $\begin{array}{l}\text { In Sadu WTP, the type of coagulation that will be used is hydraulic coagulation, } \\
\text { i.e. by utilizing the waterfall. The coagulant to be used is aluminum sulfate at a } \\
\text { dose of } 20 \mathrm{mg} / \mathrm{l} \text {. }\end{array}$ \\
\hline 3 & Flocculation & $\begin{array}{l}\text { Flocculation that will be used in the planning of Sadu WTP is hydraulic } \\
\text { flocculation with a baffled channel system. The consideration of the type of } \\
\text { hydraulic unit is based on the type of unit used at the equivalent WTP (Cipageran } \\
\text { WTP) and the efficiency of the costs to be incurred. Flocculation tanks will be } \\
\text { made as much as } 1 \text { unit with } 6 \text { compartments. }\end{array}$ \\
\hline 4 & Sedimentation & $\begin{array}{l}\text { In the planning of the WTP, two sedimentation units will be built with vertical flow } \\
\text { and use tube settlers with a slope of } 60^{\circ} \text { in the settling zone. }\end{array}$ \\
\hline 5 & Filtration & $\begin{array}{l}\text { In the planned WTP units, } 5 \text { filtration tanks will be made. The type of filtration } \\
\text { used is the rapid sand filter by using two media, i.e. sand and anthrasite and buffer } \\
\text { media, i.e. gravel. The use of dual media was chosen so that it can filter water with } \\
\text { higher turbidity and better operating time for the unit. }\end{array}$ \\
\hline 6 & Reservoir & In the planned WTP, a reservoir unit will be built with a capacity of $270 \mathrm{~m}^{3}$ each. \\
\hline
\end{tabular}




\section{Design of Sadu Water Treatment Plant}

A. Intake

The intake unit is planned to use river intake, the flow of raw water from the river to the WTP flowing gravity. The river intakes, dependent on the formation of the river bed and the amount of total suspended solids of raw water could be located onshore with the intake line preferably on piles to convey water into the onshore sump for pumping or it could be a simple offshore jetty structure to support low head borehole pumps or high pressure centrifugal pumps as required by the system (Baharodi, 2016). River intake is a type which may either located sufficiently inside the river so that demands of water are met with in all the seasons of the year, or it may be located near the river bank where a sufficient depth of water is available (Anupojo, 2016). The intake unit consists of sluice gate, bar screen, carrier channel and collecting well. The distance of the intake to the WTP is as far as $16.5 \mathrm{~km}$. Design of intake can be seen in Table 6 and intake unit sketch can be seen in Figure 4.

Table 6. Design of Intake in Sadu WTP

\begin{tabular}{|c|c|c|c|c|}
\hline No. & Description & Symbol & Unit & Obtained Value \\
\hline \multicolumn{5}{|c|}{ Sluice gate } \\
\hline 1 & Sluice gate width & & $\mathrm{m}$ & 0.525 \\
\hline 2 & $\begin{array}{l}\text { The height of the sluice gate } \\
\text { opening }\end{array}$ & & $\mathrm{m}$ & 2.11 \\
\hline \multicolumn{5}{|c|}{ Carrier channel } \\
\hline 3 & Carrier channel length & & $\mathrm{m}$ & 6 \\
\hline 4 & Carrier channel width & & $\mathrm{m}$ & 0.525 \\
\hline 5 & Carrier channel height & & $\mathrm{m}$ & 2.11 \\
\hline 6 & $\begin{array}{l}\text { Average flow velocity of } \\
\text { the carrier channel }\end{array}$ & & $\mathrm{m} / \mathrm{sec}$ & 0.67 \\
\hline \multicolumn{5}{|c|}{ Collecting well } \\
\hline 7 & Collecting well length & & $\mathrm{m}$ & 3 \\
\hline 8 & Collecting well width & & $\mathrm{m}$ & 1.5 \\
\hline 9 & Collecting well height & & $\mathrm{m}$ & 3.61 \\
\hline \multicolumn{5}{|c|}{ Pressure release tank and transmission pipe } \\
\hline 10 & $\begin{array}{l}\text { Number of press release } \\
\text { tanks }\end{array}$ & & tanks & 4 \\
\hline 11 & Transmission pipe diameter & & $\mathrm{mm}$ & 250 \\
\hline 12 & Flow velocity & $\mathrm{V}$ & $\mathrm{m} / \mathrm{sec}$ & 3 \\
\hline 13 & Press release tank length & & $\mathrm{m}$ & 2.6 \\
\hline 14 & Press release tank width & & $\mathrm{m}$ & 1.3 \\
\hline 15 & Press release tank height & & $\mathrm{m}$ & 2 \\
\hline 16 & Detention time & $\mathrm{t}_{\mathrm{d}}$ & second & 45 \\
\hline
\end{tabular}

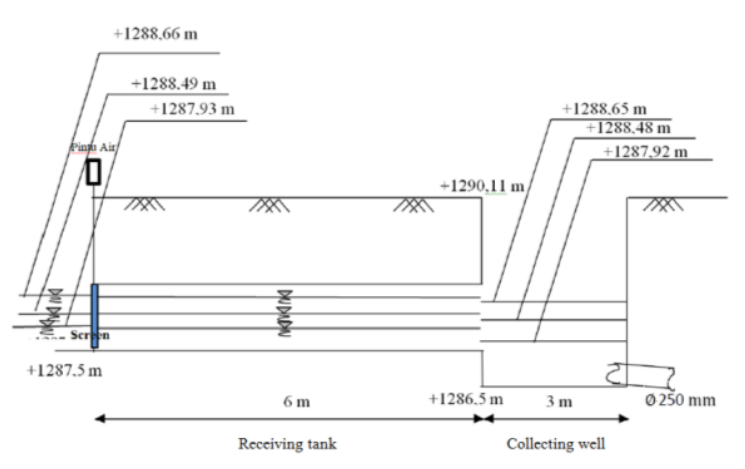

Figure 4. Intake Unit Sketch.

\section{B. Bar screen}

Screens are used in water treatment for the removal of coarse solids. Screens are either manually or mechanical cleaned. The type of screen used in Sadu WTP is a manual screen. Design of bar screen and bar screen sketch in Sadu WTP can be seen in Table 7 and Figure 5 respectively. 
Table 7. Design of Bar screen in Sadu WTP

\begin{tabular}{clccc}
\hline No. & Description & Symbol & Unit & $\begin{array}{c}\text { Obtained } \\
\text { Value }\end{array}$ \\
\hline 1 & Stem width & $\mathrm{w}$ & $\mathrm{m}$ & 0.015 \\
\hline 2 & Opening width & $\mathrm{b}$ & $\mathrm{m}$ & 0.075 \\
\hline 3 & $\begin{array}{l}\text { Total opening } \\
\text { width }\end{array}$ & $\mathrm{m}$ & 0.525 \\
\hline 4 & Slope & $\mathrm{o}$ & 90 \\
\hline 5 & Number of stems & $\mathrm{n}$ & bar & 5 \\
\hline 6 & $\begin{array}{l}\text { Number of } \\
\text { openings }\end{array}$ & gaps & 6 \\
\hline
\end{tabular}

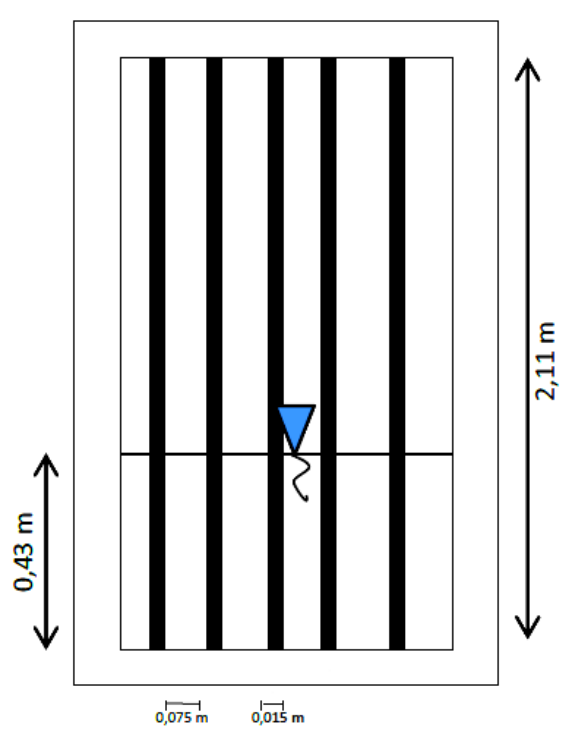

Figure 5. Bar screen Sketch

\section{Coagulation}

A very important step in water and in wastewater treatment is the coagulationflocculation process, which is widely used, due to its simplicity and cost-effectiveness. Regardless of the nature of the treated sample (e.g. various types of water or wastewater) and the overall applied treatment scheme, coagulation-flocculation is usually included, either as pre-, or as post-treatment step. The whole treatment process coagulationflocculation can be divided into two distinct procedures, which should be applied consecutively. The first one termed coagulation, is the process whereby destabilization of a given colloidal suspension or solution is taking place. The function of coagulation is to overcome the factors that promote the stability of a given system. It is achieved with the use of appropriate chemicals, usually aluminum or iron salts, the so-called coagulant agents. Coagulation usually completes in a very short period time of time (e.g. about 10 seconds) (Tzoupanos et.al, 2008).

Coagulation unit of Sadu WTP uses a type of hydraulic mixing. In the coagulation process, there is one receiving tub to collect raw water before entering the stirring tank and given the coagulant material. The raw water inlet pipe in the receiving bath is $250 \mathrm{~mm}$. The coagulant material used in Sadu WTP is aluminum sulfate with dose of $20 \mathrm{mg} / \mathrm{l}$. Design of coagulation tank and coagulation unit sketch can be seen in Table 8 and Figure 6 respectively.

Table 8. Design of Coagulation Tank in Sadu WTP

\begin{tabular}{clccc}
\hline No. & Description & Symbol & Unit & $\begin{array}{c}\text { Obtained } \\
\text { Value }\end{array}$ \\
\hline Receiving tank & & & \\
\hline 1 & $\begin{array}{l}\text { Number of } \\
\text { units }\end{array}$ & & tank & 1 \\
\hline 2 & Detention time & $\mathrm{t}_{\mathrm{d}}$ & second & 30.2 \\
\hline 3 & Length of tank & $\mathrm{L}$ & $\mathrm{m}$ & 2.6 \\
\hline 4 & Tank width & $\mathrm{W}$ & $\mathrm{m}$ & 1.3 \\
\hline 5 & Tank height & $\mathrm{H}$ & $\mathrm{m}$ & 1.8 \\
\hline 6 & Freeboard & & $\mathrm{m}$ & 0.46 \\
\hline Coagulation tank & & & \\
\hline 7 & Detention time & $\mathrm{t}_{\mathrm{d}}$ & second & 9,05 \\
\hline 8 & $\begin{array}{l}\text { Velocity } \\
\text { gradient }\end{array}$ & $\mathrm{G}$ & second & 745.48 \\
\hline 9 & Length of tank & $\mathrm{L}$ & $\mathrm{m}$ & 1.5 \\
\hline 10 & Tank width & $\mathrm{W}$ & $\mathrm{m}$ & 1.3 \\
\hline 11 & Tank height & $\mathrm{H}$ & $\mathrm{m}$ & 1.623 \\
\hline 12 & $\begin{array}{l}\text { The height of } \\
\text { the waterfall }\end{array}$ & $\mathrm{h}$ & $\mathrm{m}$ & 0.44 \\
\hline 13 & Mixing power & $\mathrm{P}$ & Watt & 801.75 \\
\hline
\end{tabular}

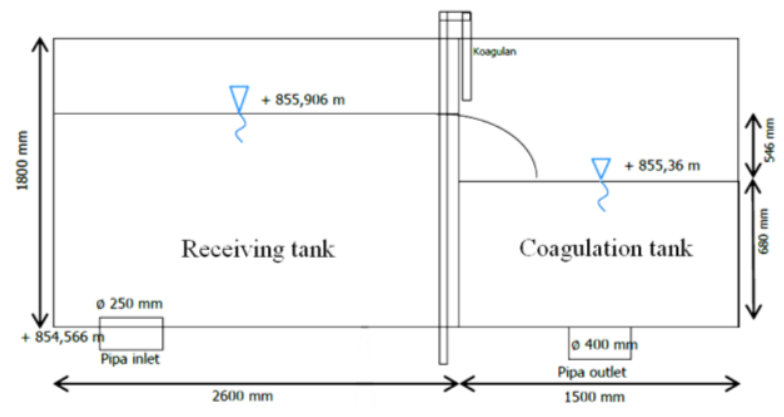

Figure 6. Coagulation Unit Sketch. 


\section{Flocculation}

The second sub-process after coagulation is flocculation, refers to the induction of destabilized particles in order to come together, to make contact and thereby, to form large agglomerates, which can be separated easier usually through gravity settling. Flocculation occurs usually over a period of 20 to 45 minutes. Coagulation-flocculation is used widely during water or wastewater treatment. It is an integral treatment step in the surface or underground waters treatment, indented for human consumption. Typical applications are the removal/separation of colloids and suspended particles, of natural organic matter, or of metal ions (Tzoupanos et.al, 2008).

Flocculation unit of Sadu WTP uses a type of hydraulic flocculation with vertical flow and consists of 6 hexagonal compartments. The velocity gradient of each compartment is different, starting with the highest compartment 1 , followed by the decreasing velocity gradient of the other compartments. Design of flocculation tank and flocculation tank sketch can be seen in Table 9 and Figure 4 respectively.

Table 9. Design of Flocculation Tank in Sadu WTP

\begin{tabular}{|c|c|c|c|c|}
\hline No. & Description & Symbol & Unit & $\begin{array}{c}\text { Obtained } \\
\text { Value }\end{array}$ \\
\hline 1 & Total detention time & $t_{d}$ total & second & 773.04 \\
\hline 2 & $\begin{array}{l}\text { Detention time per } \\
\text { compartment }\end{array}$ & $\mathrm{td}$ & second & 128.84 \\
\hline 3 & Hexagonal side & & $\mathrm{m}$ & 1.2 \\
\hline 4 & Tank height & $\mathrm{H}$ & $\mathrm{m}$ & 5.5 \\
\hline 5 & $\begin{array}{l}\text { Height of sluice } \\
\text { gate opening }\end{array}$ & & $\mathrm{m}$ & 0.85 \\
\hline 6 & $\begin{array}{l}\text { Width of sluice gate } \\
\text { opening }\end{array}$ & & $\mathrm{m}$ & 0.9 \\
\hline 7 & $\mathrm{Gt}_{\mathrm{d}}$ total & $\mathrm{Gt}_{\mathrm{d}}$ & & $48,368.5$ \\
\hline \multicolumn{5}{|c|}{ Compartment 1} \\
\hline 8 & Velocity gradient & $\mathrm{G}_{1}$ & second $^{-1}$ & 76.89 \\
\hline 9 & $\mathrm{Gt}_{\mathrm{d}}$ & $\mathrm{Gt}_{\mathrm{d} 1}$ & & 9906.5 \\
\hline 10 & Flow velocity & $\mathrm{v}_{1}$ & $\mathrm{~m} / \mathrm{sec}$ & 2.11 \\
\hline \multicolumn{5}{|c|}{ Compartment 2} \\
\hline 11 & Velocity gradient & $\mathrm{G}_{2}$ & second $^{-1}$ & 71.39 \\
\hline 12 & $\mathrm{Gt}_{\mathrm{d}}$ & $\mathrm{Gt}_{\mathrm{d} 2}$ & & 9137 \\
\hline 13 & Flow velocity & $\mathrm{V}_{2}$ & $\mathrm{~m} / \mathrm{sec}$ & 1.96 \\
\hline \multicolumn{5}{|c|}{ Compartment 3} \\
\hline 14 & Velocity gradient & $\mathrm{G}_{3}$ & second $^{-1}$ & 65.76 \\
\hline 15 & $\mathrm{Gt}_{\mathrm{d}}$ & $\mathrm{Gt}_{\mathrm{d} 3}$ & & 8375 \\
\hline 16 & Flow velocity & $\mathrm{v}_{3}$ & $\mathrm{~m} / \mathrm{sec}$ & 1.8 \\
\hline Cor & artment 4 & & & \\
\hline
\end{tabular}

\begin{tabular}{|c|c|c|c|c|}
\hline No. & Description & Symbol & Unit & $\begin{array}{c}\text { Obtained } \\
\text { Value }\end{array}$ \\
\hline 17 & Velocity gradient & $\mathrm{G}_{4}$ & second $^{-1}$ & 62.76 \\
\hline 18 & $\mathrm{Gt}_{\mathrm{d}}$ & $\mathrm{Gt}_{\mathrm{d} 4}$ & & 7957 \\
\hline 19 & Flow velocity & $\mathrm{V}_{4}$ & $\mathrm{~m} / \mathrm{sec}$ & 1.72 \\
\hline \multicolumn{5}{|c|}{ Compartment 5} \\
\hline 20 & Velocity gradient & $\mathrm{G}_{5}$ & second $^{-1}$ & 59.43 \\
\hline 21 & $\mathrm{Gt}_{\mathrm{d}}$ & $\mathrm{Gt}_{\mathrm{d} 5}$ & & 7504 \\
\hline 22 & Flow velocity & $\mathrm{V}_{5}$ & $\mathrm{~m} / \mathrm{sec}$ & 1.63 \\
\hline \multicolumn{5}{|c|}{ Compartment 6} \\
\hline 23 & Velocity gradient & $\mathrm{G}_{6}$ & second $^{-1}$ & 41.32 \\
\hline 24 & $\mathrm{Gt}_{\mathrm{d}}$ & $\mathrm{Gt}_{\mathrm{d} 6}$ & & 5489 \\
\hline 25 & Flow velocity & $\mathrm{V}_{6}$ & $\mathrm{~m} / \mathrm{sec}$ & 0.25 \\
\hline
\end{tabular}

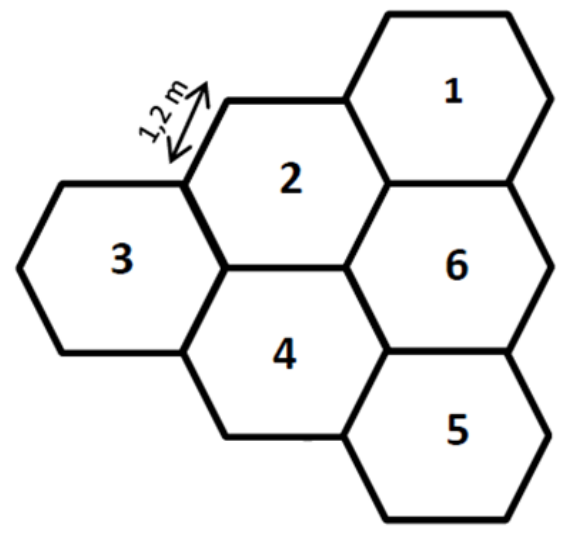

Figure 7. Flocculation Unit Layout.

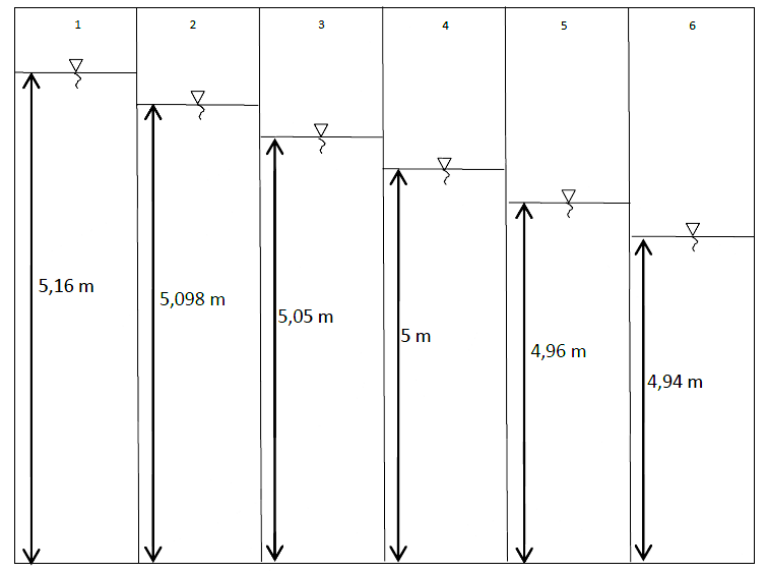

Figure 8. Sketch of Flocculation Unit Water Level Reduction.

\section{E. Sedimentation}

Sedimentation is a physical water treatment process using gravity to removes suspended solids from water. Solid particles entrained by the turbulence of moving water may be removed naturally by sedimentation in the still water of lakes and oceans. Settling basin are ponds 
constructed for the purpose of removing entrained solids by sedimentation. Conventional settling units represent around one-third of the total capital cost of water treatment plants because of land and construction costs. Many alternatives have been developed to enhance the performance of settling tanks, increase their hydraulic capacity and decrease their capital or operational costs. Some of these alternatives, such as inclined plates, increase the surface area available for settling and enhance the hydraulic conditions, whereas others, such as alum, improve the settling properties of the suspension (Al-Kizwini, 2015).

Sedimentation unit of Sadu WTP is divided into two tanks. Each sedimentation tank is equipped with a tube settler with a slope of $60^{\circ}$ and there are two sludge spaces per sedimentation tank. In the sedimentation basin, the process of settling or separating particles contained in water is deposited by gravity. Design of sedimentation tank and sedimentation tank sketch can be seen in Table 10 and Figure 9.

Table 10. Design of Sedimentation Tank in Sadu WTP

\begin{tabular}{|c|c|c|c|c|}
\hline No. & Description & Symbol & Unit & $\begin{array}{c}\text { Obtained } \\
\text { Value }\end{array}$ \\
\hline \multicolumn{5}{|c|}{ Dimensions of Sedimentation Tank } \\
\hline 1 & Number of tanks & & amounts & 2 \\
\hline 2 & $\begin{array}{l}\text { Discharge per } \\
\text { tank }\end{array}$ & Q & $\mathrm{m}^{3} / \mathrm{second}$ & 0.075 \\
\hline 3 & Surface loading & $\mathrm{v}_{0}$ & $\mathrm{~m}^{3} / \mathrm{m}^{2} \cdot \mathrm{sec}$ & $\begin{array}{c}1.076 \times \\
10^{-3}\end{array}$ \\
\hline 4 & Length of tank & $\mathrm{L}$ & $\mathrm{m}$ & 17.8 \\
\hline 5 & Tank width & W & $\mathrm{m}$ & 4 \\
\hline 6 & Tank height & $\mathrm{H}$ & $\mathrm{m}$ & 5.1 \\
\hline \multicolumn{5}{|c|}{ Settling zone } \\
\hline 7 & $\begin{array}{l}\text { Tube settler } \\
\text { slope }\end{array}$ & & $\circ$ & 60 \\
\hline 8 & Thick tube & & $\mathrm{mm}$ & 0.7 \\
\hline 9 & Length of tube & & $\mathrm{m}$ & 1 \\
\hline 10 & Tube height & & $\mathrm{m}$ & 1 \\
\hline 11 & Number of tubes & & tubes & 9398 \\
\hline
\end{tabular}

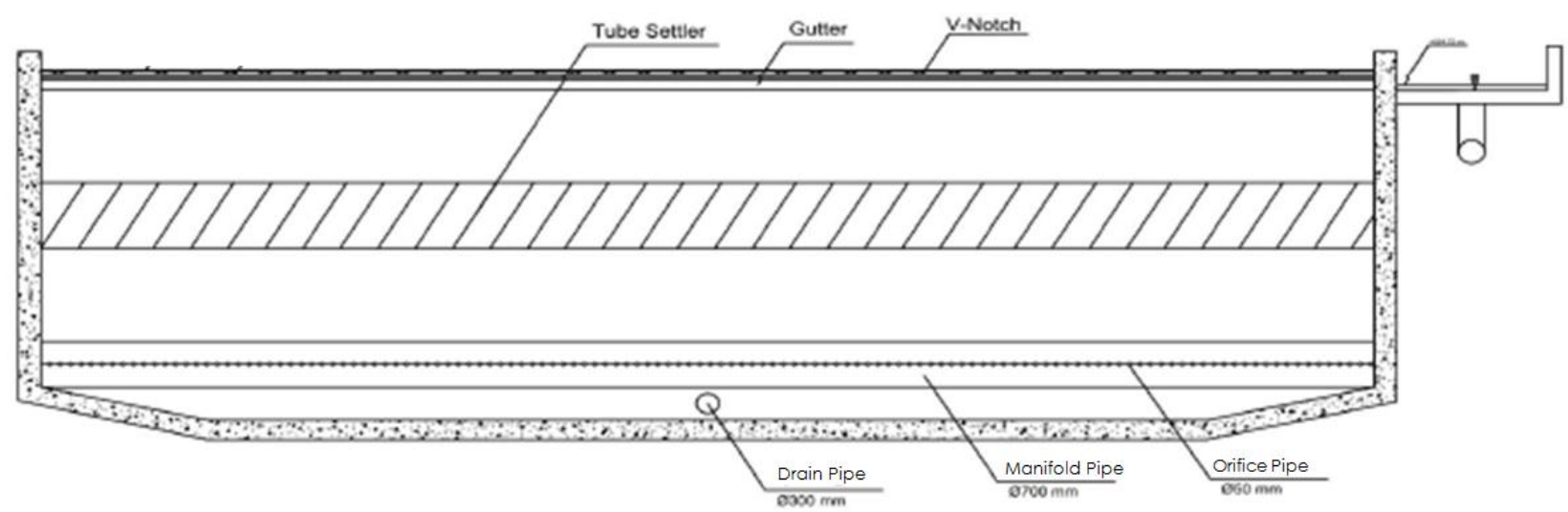

Figure 9. Sedimentation Unit Sketch

\section{F. Filtration}

The main process of water treatment can be mechanical, chemical and biological. From all mechanical treatment procedures, filtration is the most irreplaceable one in the scheme of a treatment plant. Filtration is the advanced clearing procedure, consisting of water passing through a porous material that has a certain granulometry, named filter layer, used for the retention of the natural suspended particles or previous coagulated particles. Filtering is influenced by a series of parameters (Oana, 2011).

The filtration unit is designed using a rapid sand filter type with dual media filters, i.e. sand and anthrasite media and added gravel buffer. The filtration unit consists of 5 tanks with a capacity of $30 \mathrm{l} / \mathrm{sec}$ per tank. Design of filtration tank and filtration tank sketch in Sadu WTP can be seen in Table 11 and Figure 10 respectively. 
Table 11. Design of Filtration Tank in Sadu WTP

\begin{tabular}{clccc}
\hline No. & Description & Symbol & Unit & $\begin{array}{c}\text { Obtained } \\
\text { Value }\end{array}$ \\
\hline 1 & $\begin{array}{l}\text { Discharge of } \\
\text { filtration }\end{array}$ & Qtotal & $\mathrm{m}^{3} / \mathrm{sec}$ & 0.15 \\
\hline 2 & Number of tank & & tanks & 5 \\
\hline 3 & $\begin{array}{l}\text { Discharge per } \\
\text { tank }\end{array}$ & $\mathrm{Q}$ & $\mathrm{m}^{3} / \mathrm{sec}$ & 0.03 \\
\hline 4 & Length of tank & $\mathrm{L}$ & $\mathrm{m}$ & 7.2 \\
\hline 5 & Tank width & $\mathrm{W}$ & $\mathrm{m}$ & 2.4 \\
\hline 6 & Filtration velocity & $\mathrm{v}$ & $\mathrm{m} / \mathrm{sec}$ & 6.25 \\
\hline 7 & $\begin{array}{l}\text { Anthrasite media } \\
\text { thickness }\end{array}$ & & $\mathrm{cm}$ & 40 \\
\hline 8 & $\begin{array}{l}\text { Sand media } \\
\text { thickness }\end{array}$ & & $\mathrm{cm}$ & 25 \\
\hline 9 & $\begin{array}{l}\text { Gravel media } \\
\text { thickness }\end{array}$ & & $\mathrm{cm}$ & 20 \\
\hline
\end{tabular}

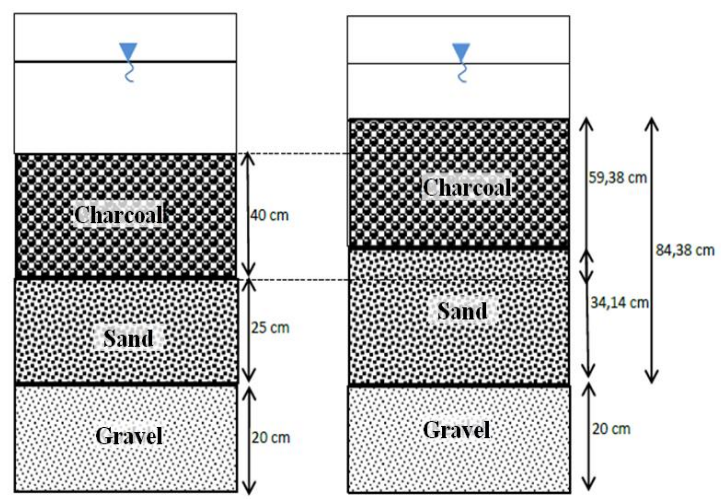

Figure 10. Filtration Unit Sketch

\section{G. Reservoir}

The function of the reservoir is to hold water that will be distributed to consumers (Alfatih, et.al, 2017), (Setyowati, et.al, 2016). Filtered water can be used for drinking water. Reservoir is water storage tank located at the installation. The treated water is stored in this tank for later transfer to the distribution system. Design of reservoir includes selection of size and shape; other considerations include protection against stored water, protection of reservoir structure, and protection of reservoir maintenance workers (Qasim, 2000).

Chlorine is added to the water to kill and/or inactive any remaining pathogens. Water is often disinfected before it enters the distribution system to ensure that potentially dangerous microbes are killed. Chlorine, chloramines, or chlorine dioxide are most often used because they are very effective disinfectants, not only at the treatment plant but also in the pipes that distribute water to our homes and businesses (Angreni, 2009).

In Sadu WTP, the chlorination process takes place after the treatment (post chlorination), i.e. by adding chlorine to the reservoir. The concentration of chlorine used in Sadu WTP is $12 \%$ with a chlorine dose of $2 \mathrm{mg} / \mathrm{l}$. Chlorine needs per month is $777.6 \mathrm{~kg} / \mathrm{month}$. Design of reservoir tank and reservoir tank sketch can be seen in Table 11 and Figure 11 respectively.

Table 11. Design of Reservoir in Sadu WTP

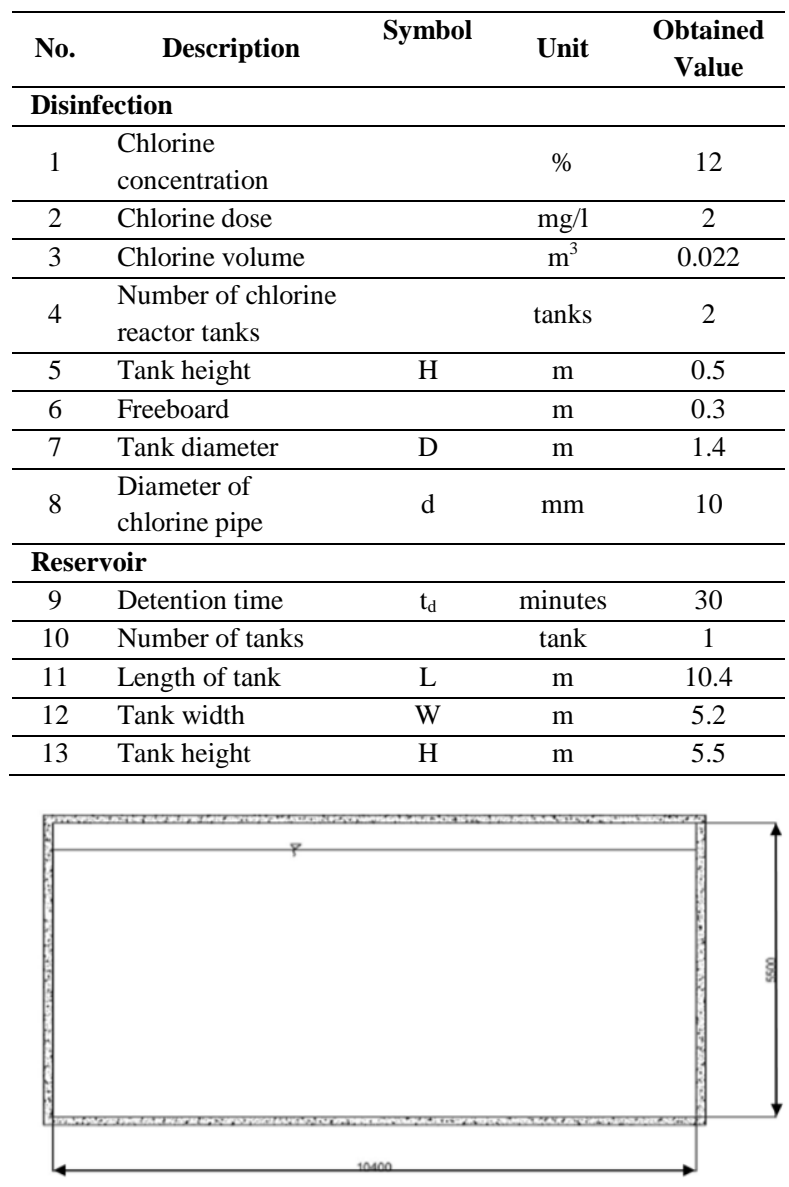

Figure 11. Reservoir Unit Sketch. 


\section{Conclusion}

In designing drinking water treatment, the parameters under review are those that exceed the standard of quality according to the Minister of Health Regulation No. 492 of 2010, i.e. turbidity, BOD, COD and fecal coliform. There were two alternative proposed (Alternative I and Alternative II) in drinking water treatment, i.e. complete unit (Alternative I) consisting of intake; hydraulic coagulation; hydraulic flocculation; tube settler sedimentation; rapid sand filter; reservoir; disinfection; and sludge drying bed, and slow sand filter unit (Alternative II) consisting of intake, pre-sedimentation, slow sand filter, reservoir, disinfection, and sludge drying bed. Based on the results of the scoring obtained in multi criteria analysis, the complete treatment unit has the highest score, i.e. 4.05, so the alternative treatment used in the Sadu WTP is the complete treatment unit (Alternative I). The intake unit is planned to use river intake, the flow of raw water from the river to the WTP flowing gravity. Coagulation unit of Sadu WTP uses a type of hydraulic mixing. Flocculation unit of Sadu WTP uses a type of hydraulic flocculation with vertical flow and consists of 6 hexagonal compartments. Sedimentation unit of Sadu WTP is divided into two tanks. Each sedimentation tank is equipped with a tube settler with a slope of $60^{\circ}$ and there are two sludge spaces per sedimentation tank. The filtration unit is designed using a rapid sand filter type with dual media filters, i.e. sand and anthrasite media and added gravel buffer.

\section{Daftar Pustaka}

Alfatih, I.Z., Warnana, D.D., Wijaya, P.H. (2017). Klasifikasi Fasies pada Reservoir Menggunakan Crossplot Data Log PWave dan Data Log Density. Jurnal Teknik ITS, vol. 6 (1): B127-B130.

Al-Kizwini, R.S.. (2015). Improvement of Sedimentation Process Using Inclined
Plates. Mesopotamia Environmental Journal, vol. 2, No.1: 100-114.

Angreni, E. (2009). Review on Optimization of Conventional Drinking Water Treatment Plant. World Applied Sciences Journal 7(9): 1144-1151.

Anupoju. S. (2016).What are Intake Structures? 8 Types of Intake Structures. The Constructor Civil Engineering Home.

Baharodi, A. (2016). Water Supply and Distribution Systems. Essential of Oil and Gas Utilities. Process Design, Equipment, and Operations, pages 225-328.

Hasbiah, A.W., Rusmaya, D., Apriani, D. (2019). Sanitasi Berbasis Masyarakat di Pesantren Putri Al-Ittihad, Kabupaten Cianjur. Journal of Community Based Environmental Engineering and Management, vol. 3 (1): 1-8.

Oana, T., Valentin, N., and Gabriel, L. (2011). Actual Stage of Water Filtration. Journal of Engineering Studies and Research, vol. 17, No.4.

Smith, R., Van de Loo, J., Van den Boomen, M., Khakzad, N., Van Heck, G.J., and Wolfert, A.R.M. (2019). Long-term Availability Modelling of Water Treatment Plants. Journal of Water Process Engineering, vol. 28, 203-213.

Qasim, S.R.. (2000). Wastewater Treatmnet Plant: Planning, Design, and Operation. New York.

Setyowati, R.D.N., Junaidi, R. (2016). Analisis Routing Reservoir dalam Pengembangan Sumber Daya Air Kawasan Karst. Al-Ard, vol. 2 (1): 16-22.

Tzoupanos, N.D. and Zouboulis, A.I. (2008). Coagulation-Flocculation Processes in Water/Wastewater Treatment: The Application of New Generation of Chemical Reagents. International 
Conference on Heat Transfer, Thermal Engineering and Environment, pp 20-22.

Udimal, T.B, Jincai, Z., Ayamba, E.C., and Owusu. S.M. (2017). China's Water
Situation; The Supply of Water and The Pattern of Its Usage. International Journal of Sustainable Built Environment, 6, 491500. 